\title{
Lopinavir/ $\mathrm{r}$ + Efavirenz combination as a potent NRTI sparing antiretroviral therapy
}

\author{
Philippe Henrivaux ${ }^{1 *}$, Yvette Fairon ${ }^{2}$, Benoît Kabamba ${ }^{3}$, Jean-Cyr Yombi ${ }^{4}$, Patrick Goubau ${ }^{3}$, Bernard Vandercam ${ }^{4}$ \\ From $16^{\text {th }}$ International Symposium on HIV and Emerging Infectious Diseases \\ Marseille, France. 24-26 March 2010
}

\section{Background}

Classical recommended HAART are NRTI+PI or NRTI +NNRTI combinations. However, some of our HIV patients have already long durations of NRTI exposure with confirmed or beginning NRTI toxicities. NNRTI + PI combinations could be proposed to avoid further exposure to NRTI.

\section{Methods}

We review the data of 19 patients heavely preexposed to NRTI and submitted to a Lopinavir/r + Efavirenz (Lpv/r $2 \times 3$ tablets $200 \mathrm{mg} / 50 \mathrm{mg} / \mathrm{d}+\mathrm{EFZ} 1 \times 1$ tablet 600 $\mathrm{mg} / \mathrm{d}$ ) combination. Results are expressed as means \pm sem.

\section{Results}

Nineteen patients (7 F/12 M; 8 Africans, 1 Asiatic, 11 Caucasians) were submitted to $\mathrm{Lpv} / \mathrm{r}+\mathrm{EFZ}$ during a total period of 618,5 patient-months (33 \pm 5 months). These patients were $47 \pm 2$ years old and are regularly followed for their HIV seropositivity since $123 \pm 9$ months. Duration of exposure to any ART before inclusion in this study was $92 \pm 10 \mathrm{~m}$. Three patients discontinued EFZ rapidly for allergic reactions (2) or psychiatric deterioration (1), and one discontinued after $16 \mathrm{~m}$ due to persistently sleep disturbances. Seven patients discontinued for hyperlipemia after $30 \pm 5 \mathrm{~m}$. Viral loads remained undetectable $(\mathrm{PCR}<5$ copies $\mathrm{RNA} / \mathrm{ml})$ and \% CD4 continued to increase to reach a mean value of $25 \pm 2 \%$.

\section{Discussion}

The long term follow-up of this small cohort heavely pre-exposed to NRTI suggests that Lpv/r+EFZ is a potent antiviral therapy and that further NRTI combinations therapy can be avoided in these patients. The

\footnotetext{
* Correspondence: philippe.henrivaux@skynet.be

${ }^{1} \mathrm{CHC}$ Clinique St Joseph, Médecine Interne, Liège, Belgium
}

tolerance to each drug seems not modified by their use when combined. However, hyperlipemia is a regular preoccupation.

\section{Author details}

${ }^{1} \mathrm{CHC}$ Clinique St Joseph, Médecine Interne, Liège, Belgium. ${ }^{2} \mathrm{ASBL}$, Liège, Belgium. ${ }^{3}$ Laboratoire de Référence SIDA, Cliniques Universitaires Saint Luc, Brussels, Belgium. ${ }^{4}$ Centre de Référence SIDA, Cliniques Universitaires Saint Luc, Brussels, Belgium.

Published: 11 May 2010

\section{doi:10.1186/1742-4690-7-S1-P55}

Cite this article as: Henrivaux et al:: Lopinavir/r + Efavirenz combination as a potent NRTI sparing antiretroviral therapy. Retrovirology 2010 7(Suppl 1):P55
Submit your next manuscript to BioMed Central and take full advantage of:

- Convenient online submission

- Thorough peer review

- No space constraints or color figure charges

- Immediate publication on acceptance

- Inclusion in PubMed, CAS, Scopus and Google Scholar

- Research which is freely available for redistribution 